cores from the south-central North Atlantic. Nature. $216,253$.

Blow, W. H., 1969. Late Middle Eocene to Recent planktonic foraminiferal biostratigraphy. Proc. First Intern. Conf. Plank. Microfossils, Geneva 1967. 1, 199.

Cox, A., 1969. Geomagnetic reversals. Science. 163 (3864), 237.

Cox, A., Doell, R. R. and Dalrymple, G. B., 1963. Geomagnetic polarity epochs. Science. 142, 382 .

Dalrymple, G. B., Cox, A., Doell, R. R. and Gromme, C. S., 1967. Pliocene geometric polarity epochs. Earth Planet. Sci. Lett. 2, 163.

Foster, J. H. and Opdyke, N. D., 1970. Upper Miocene to Recent magnetic stratigraphy in deep-sea sediments. $J$. Geophs. Res. 75, 4465 .

Glass, B., Ericson, D. B., Heezen, B. C., Opdyke, N. D. and Glass, J. A., 1967. Geomagnetic reversals and Pleistocene chronology. Nature. 216 (5114), 437.

Harrison, C. G. A. and Funnell, B. M., 1964. Relationship of paleomagnetic reversals and micropaleontology in two late Cenozoic cores from the Pacific Ocean. Nature. 204, 566.

Hays, J. D. and Opdyke, N. D., 1967. Antarctic Radiolaria, magnetic reversals and climatic changes. Science. 158, 1001.

Hays, J. D. and Berggren, W. A., 1971. Quaternary boundaries and correlations. In The micropaleontology of the oceans. Cambridge (Cambridge Univ. Press). 669.

Hays, J. D., Saito, T., Opdyke, N. D. and Burckle, L. H., 1969. Pliocene-Pleistocene sediments of the equatorial Pacific. Their paleomagnetic, biostratigraphic and climatic record. Bull. Geol. Soc. Am. 80, 1481.

Heirtzler, J. R., Dickson, G. O., Herron, E. M., Pitman, W. C. and Le Pichon, X., 1968. Marine magnetic anomalies, geomagnetic field reversals, and motions of the ocean floor and continents. J. Geophys. Res. 73 (6), 2119.

Irving, E., 1964. Paleomagnetism and its application to geological and geophysical problems. New York (John Wiley and Sons). 1.

McDougall, I. and Wensink, H., 1966. Paleomagnetism and geochronology of the Pliocene-Pleistocene lavas in Iceland. Earth Planet. Sci. Lett. 1, 232.

Ninkovich, D., Opdyke, N. D., Heezen, B. C. and Foster, J. H., 1966. Paleomagnetic stratigraphy, rates of deposition and tephrachronology in North Pacific deep-sea sediments. Earth Planet. Sci. Lett. 1, 476.

Olausson, E., 1965. Evidence of climatic changes in North Atlantic deep-sea cores. Progress in Oceanography. (Pergamon Press). 3, 221.

Opdyke, N. D., 1972. Paleomagnetism in deep-sea cores. Reviews of Geophysics and Space Physics. 10, 213.

Opdyke, N. D., Glass, B., Hays, J. D. and Foster J. H., 1966. A paleomagnetic study of Antarctic deep-sea sediments. Science. 154, 349 .

Pitman, W. C. and Heirtzler, J. R., 1966. Magnetic anomalies over the Pacific Antarctic ridge. Science. 154, 1164.

Ryan, W. B. F. Late Quaternary stratigraphy of the eastern Mediterranean. VII Intern. Sediment. Congr. (in press).

Talwani, M., Windish, C. C. and Langseth, M. G., Jr., 1971. Reykjanes ridge crest: a detailed geophysical study. $J$. Geophys. Res. 76, 473.

Van Couvering, J. A. and Miller, J. A., 1971. Late Miocene marine and nonmarine timescale in Europe. Nature. 230 559.

Vine, F. J., 1968. Magnetic anomalies associated with mid-ocean ridges. In The History of the Earth's Crust. Princeton, N.J. (Princeton University Press). 73.

\title{
47.3. PALEONTOLOGICAL EVIDENCE OF CHANGES IN THE PLIOCENE CLIMATES
}

N. Ciaranfi, Institute of Geology and Paleontology, University of Bari, Bari, Italy M. B. Cita, Institute of Paleontology, University of Milan, Milan, Italy

\section{INTRODUCTION}

During the shipboard investigations of the Pliocene sections continuously cored at Sites 132 (Tyrrhenian Basin) and 125/125A (Mediterranean Ridge, Ionian Basin), changes in the foraminiferal associations were noticed. It was suspected that fluctuations in assemblages at various stratigraphic horizons had been influenced by a combination of then unknown paleoenvironmental factors, notwithstanding the ever present interaction of biological evolution.

The purpose of the present study was to examine in some detail the populations of foraminifera in the Pliocene sedimentary sequences from these two sites in an attempt to learn something about ecological responses of the fauna which can be attributed particularly to changes in the Pliocene climate of the Mediterranean region.
It was anticipated early in the cruise that what we thought were fluctuations in faunal diversity would reflect past environmental variations in the Mediterranean. Caution was required at first because initial observations showed that in the Pliocene sediments diversity, as measured by the number of taxa in any single association, is not highly variable and is far less variable than in the Glacial Quaternary, where changes from less than ten to more than twenty taxa have been observed within one core section (1.5 $\mathrm{m}$ of sediment), during a time period when distinct climatic changes were known to have occurred (see Chapter 46). The number of taxa recorded in the Pliocene sediments ranges from fifteen to twenty-five, with fluctuations amounting to mostly less than twenty-five per cent.

\section{The Possibility of Using Certain Genera}

The number of species belonging to the genera Globigerina, Globigerinoides, and Globorotalia is highly vari- 
able. Because these genera have a wide range of distribution in the present oceans of the world, perhaps it is their variability which has paleoclimatic significance. They are naturally useful because of their repeated presence throughout the time interval under consideration.

Nevertheless, as a consequence of controversies concerning the taxonomy of some well-known species, particularly those representative of the genus Globorotalia, the past may not always be decipherable in terms of the present. For instance, Globorotalia puncticulata, which is one of the most conspicuous components of the Lower Pliocene assemblages and is even used as a zonal marker for the Mediterranean Pliocene, is said to have become extinct (see Bertolino et al., 1968; Cati et al., 1968). However, others, working with plankton collected in tows from surface ships, report this taxon as living today in the North Atlantic (Cifelli, 1965). Can this taxon be one and the same? Or do we, apparently, have a different taxon recorded under the same specific name in the Pliocene sediments of the Mediterranean area?

\section{Caution as to the Use of Some Species}

The use of planktonic foraminifera as climatic indicators has recently been discussed by a number of authors, including Boltovskoy (1969) and Cifelli (1971). The particular use of Globorotalias as climatic indicators has to be carefully evaluated since most of the living species are not surface dwellers, but, instead, live at various depths in the subsurface of the sea (Bé, 1969; Bé, 1960; Bé and Hamlin, 1967; Ruddimann, Tolderlund, and Bé, 1969; Bé and Tolderlund, 1971). According to the data published by these authors, Globorotalia inflata (d'Orbigny), Globorotalia hirsuta (d'Orbigny), and Globorotalia truncatulinoides (d'Orbigny) are all mesopelagic, occupying a depth habitat understood to be between 100 and 300 meters, while $G$. scitula (Brady) is an abyssopelagic species (to 1000 meters). Therefore, their abundance does not necessarily indicate a warming or cooling of the superficial waters, but may well be related to factors other than changes in temperature at, or near, the surface of the oceans, such as changes in the structure of the thermocline, or changes in salinity.

Another complication arises in the use of species which are now extinct; for example, Globorotalia aemiliana Colalongo and Sartoni, G. margaritae Bolli and Bermudez, G. tosaensis Takayanagi and Saito, Globigerina apertura Cushman, Globigerinoides cf. G. fistulosus (Schubert), and G. bollii Blow. Certainly, any paleoclimatic interpretation based on their past distributions must be considered speculative,

\section{METHOD}

In this study, a number of different population curves of the planktonic foraminifera have been built before attempting to recognize patterns of climatic change. All the curves so constructed, with the exception of one, are based on the number of taxa (species or subspecies) alone as independent from the number of specimens belonging to any single species. The evaluation of the number of taxa has been carried out by examining all the foraminiferal assemblages present in the fraction greater than 63 microns. They were obtained after sieving about $5 \mathrm{cc}$ of (wet) sediment.

\section{Explanation of the Curves}

The different curves are plotted in Figures 1, 2, and 3, each figure illustrating variations in the sedimentary sequence of an individual drill hole, i.e., Holes 125, $125 \mathrm{~A}$, and 132 respectively. The following comments pertain to the different columns in each of the figures.

1) The left-hand column of each figure, labeled "faunal abundance," shows the variation in the quantity of sediment greater than 63 microns, whose fraction consists entirely of foraminiferal shells. The values are comparable between different levels since the samples taken from shipboard cores were constant in size. Comparison should not be made with core catcher samples, however, since the quantity of sediment treated there is often variable and may be distinctly more than $5 \mathrm{cc}$. Therefore, a number of peaks corresponding to the core catcher samples, especially in Holes 132 and 125, do not represent an actual change of the faunal abundance.

The minimal values in the "faunal diversity" curve observed in the three sedimentary columns correspond to a stratigraphic interval in Holes 125 and 125A immediately overlying the late Miocene evaporites, and, in Hole 132, to an interval belonging to the Lower Pliocene (Globorotalia margaritae margaritae Lineage Zone) immediately overlying the Sphaeroidinellopsis Acme Zone. ${ }^{1}$

2) Column two contains a curve of the faunal diversity as represented by the number of individual taxa recorded in each sample. ${ }^{2}$ No direct correlation is apparent between this curve and the first one.

3) Columns three, four, and five refer to the number of taxa present in each given assemblage which belong to the genera Globorotalia, Globigerina, and Globigerinoides respectively. We note that the Globigerina curve has trends which are opposite to those of the Globorotalia and Globigerinoides curves. These latter more or less mimic each other.

Most of the taxa belonging to the genus Globigerina have a wide distribution and thus do not appear to be greatly influenced by temperature changes. Among the species recorded here in the Pliocene sections, only Globigerina digitata Brady is considered to be highly temperature sensitive. ${ }^{3}$ The taxa Globigerina bulloides d'Orbigny and $G$. quinqueloba Natland are scarcely temperature sensitive (group III, ranking numbers 21 and 22 out of 27 species considered in Douglas, 1970), while G. pachyderma (Ehrenberg) has the lowest temperature sensitivity (group $\mathrm{V}$, ranking number 25 out of 27 in the same study). Other taxa such as Globigerina bulbosa Le Roy, G. falconensis

\footnotetext{
${ }^{1}$ The level immediately overlying the Sphaeroidinellopsis Acme Zone in Hole 132 was the only place where we observed partial solution of the foraminiferal tests. For discussion of this finding, the reader is referred to Chapter 42.1 of this volume.

${ }^{2}$ These taxa are listed in the range charts for each hole. They can be found in tabular form in Chapter 7 for Holes 125 and 125A and in Chapter 13 for Hole 132. To avoid unnecessary repetition they are not reproduced here.

${ }^{3}$ It belongs to Group II (number 15 out of 27 taxa) in a ranking of decreasing temperature sensitivity according to Douglas (1970). Yet, we must point out that only the ancestral form $G$. praedigitata Parker is present in our material, and we have no data available for this taxon.
} 
SITE 125 (IONIAN BASIN)

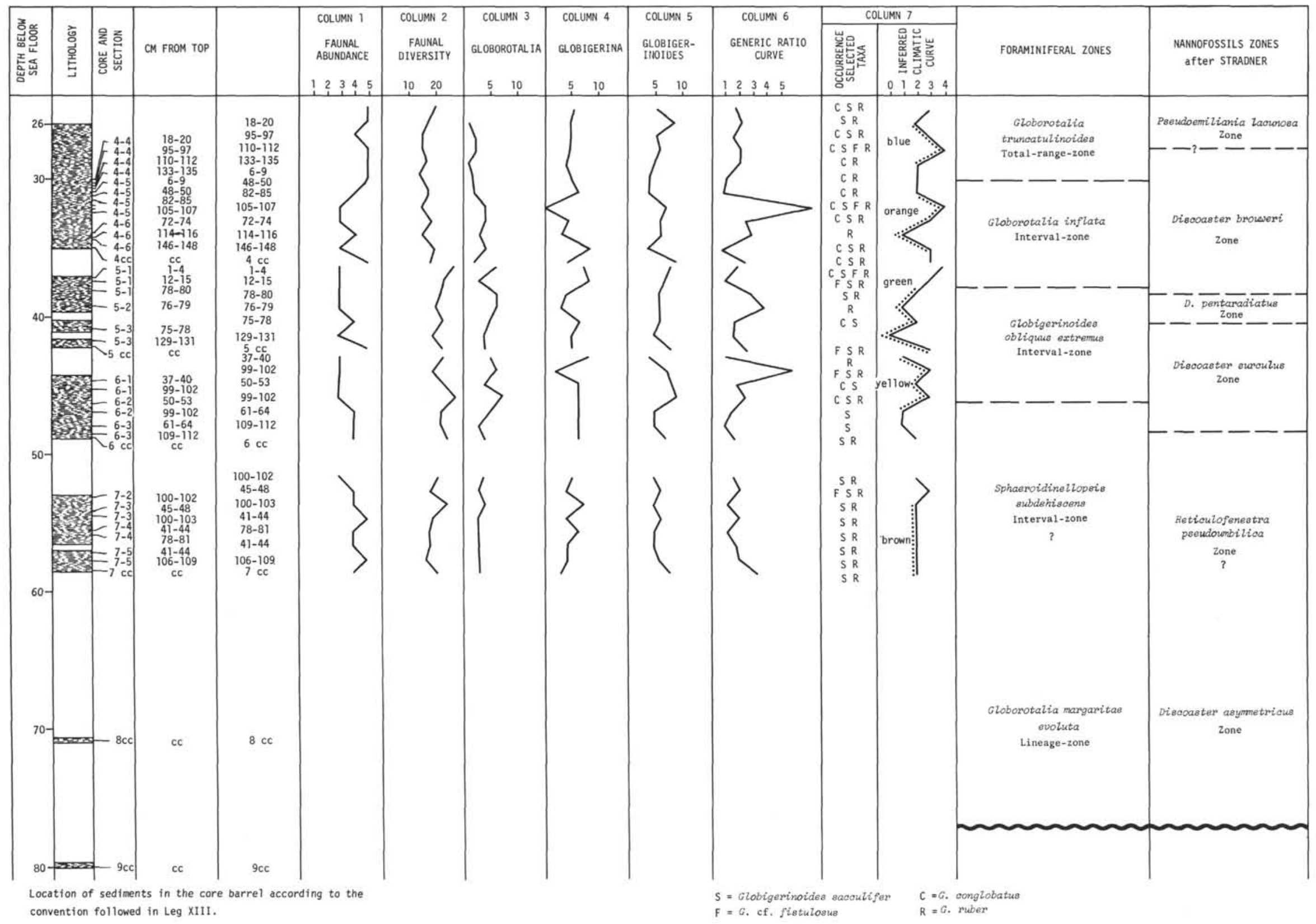
convention followed in Leg XIII. 


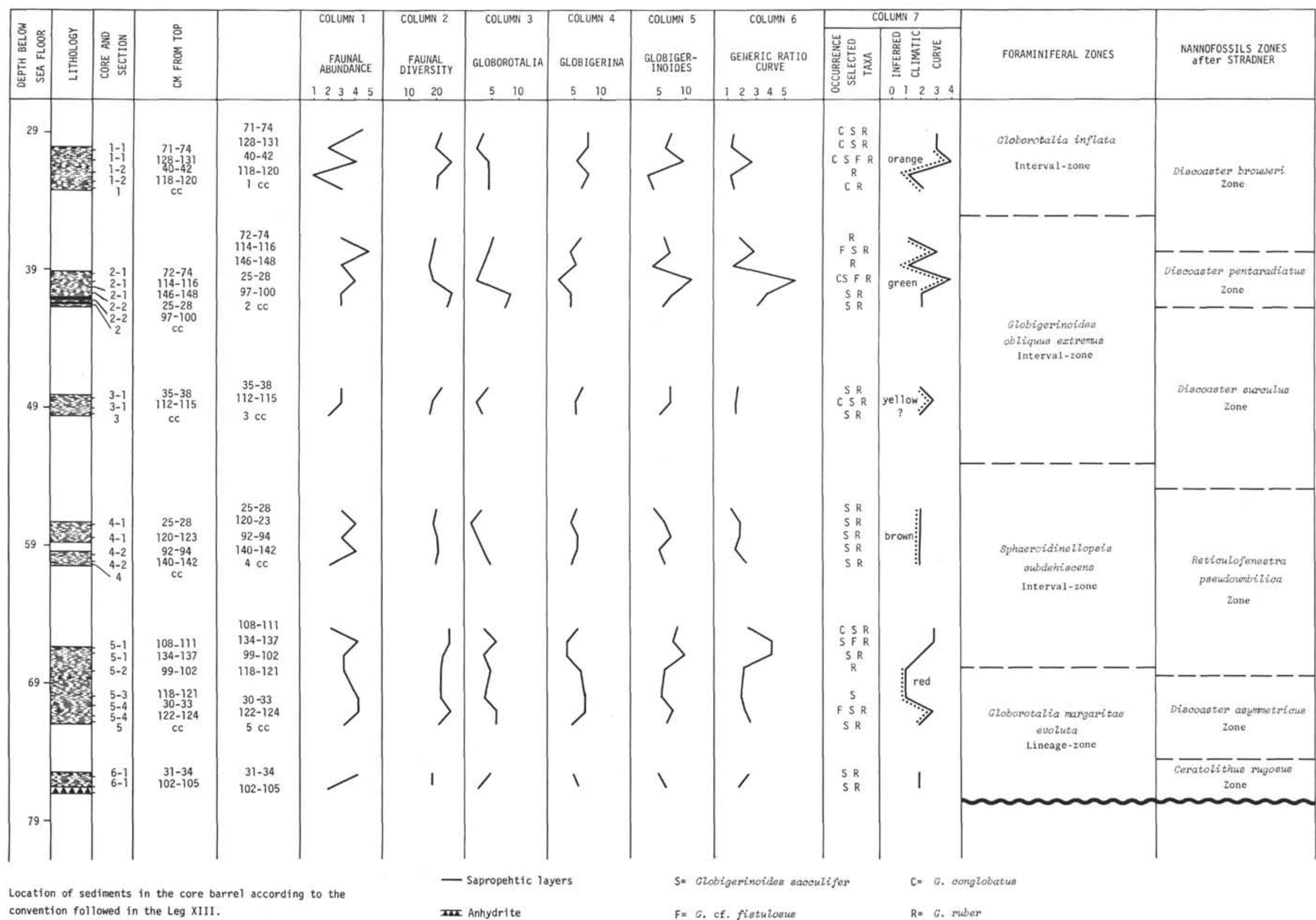

Figure 2. Lithologic succession at Site 125A (Ionian Basin), faunistic curves and biozones concerning 37 samples investigated. 
SITE 132 (TYRRHENIAN BASIN)

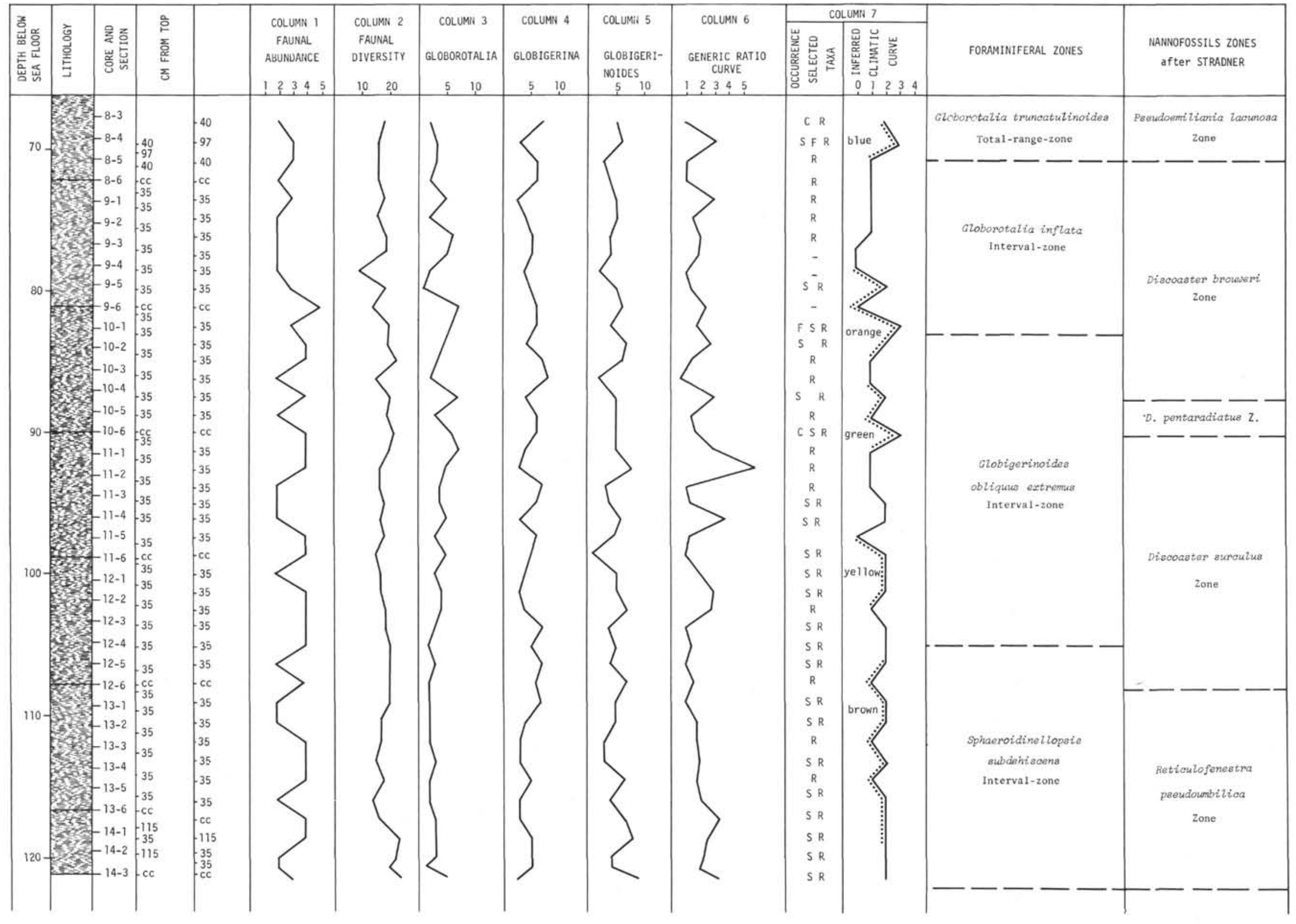



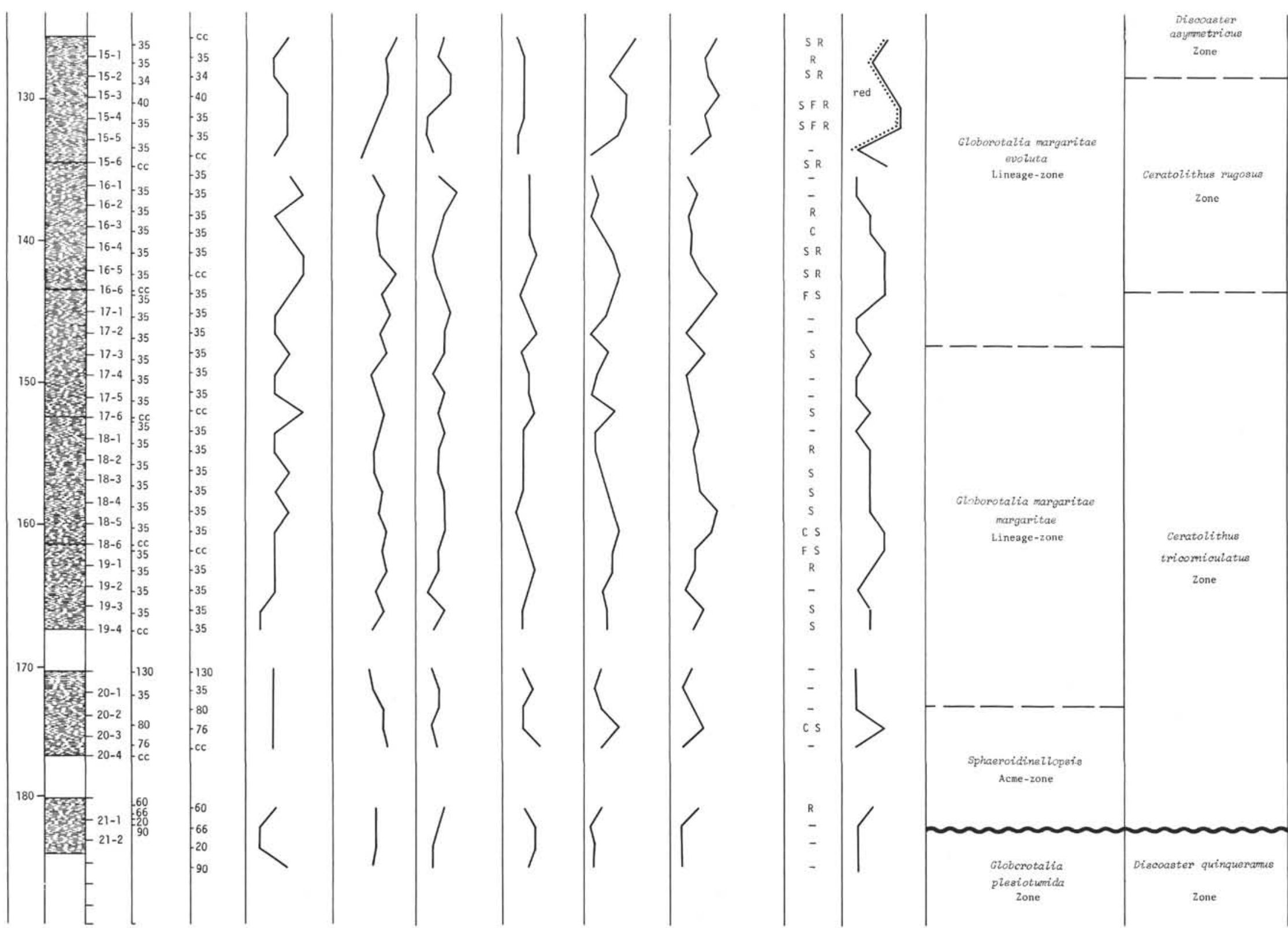

$z$
2
0
0
3
3
3
3
0
0
3
3

Location of sediments in the core barrels

according to the convention followed in Leg XIII.

Figure 3. (Continued)

$S=$ clobigerinoides sacoulifer

$\mathrm{F}=c$. of. fistulosus
$\mathbf{C}=G$. conglobatus

$R=6$. ruber 
Blow, G. microstoma Cita, Premoli Silva, and Rossi, though also recorded from the Quaternary, have not as yet been considered by workers investigating the distribution of planktonic foraminifera in the present seas. Unfortunately, their ecologic preferences are not yet known.

According to pertinent literature, practically all the species of Globigerinoides and most of the Globorotalias are distributed in the central water masses and in the tropical areas (Bé and Hamlin, 1967; Ruddimann, Tolderlund and Bé, 1969; Bé and Tolderlund, 1971). The above observations refer to the present day distribution. Yet, they may well be applied to the Pliocene, at least for the species of Globigerinoides which are still living.

4) Column six indicates variations in the values of the sum of the taxa belonging to the genus Globigerinoides and of those belonging to the genus Globorotalia divided by the number of taxa belonging to the genus Globigerina. The resulting ratio varies between 1 and 6 , with negative values having never been observed. This curve, call the "generic ratio curve," accentuates changes in the numerical composition of the three considered genera, two of which fluctuate sympathetically (Globorotalia and Globigerinoides); the third is in opposition (Globigerina).

5) The last column on the right in each figure is based on the occurrence in each given assemblage of representatives of the following species of Globigerinoides:

Globigerinoides conglobatus (Brady)

Globigerinoides cf. fistulosus (Schubert)

Globigerinoides ruber (d'Orbigny)

Globigerinoides sacculifer (Brady)

All of these species, except $G$. cf. fistulosus, are living in the present seas. Unfortunately, however, there is no literature concerning their present day distribution in the Mediterranean. Therefore, the preference of any particular species for a certain climatic belt can only be inferred from their observed distribution in other areas such as the Atlantic, where considerable data from plankton tows are available (Bé and Hamlin, 1967; Bé and Tolderlund, 1971). ${ }^{4}$

A synopsis of the latitudinal range of the three living taxa in the North Atlantic is shown in Figure 4.

Since the climatic response of these four selected species is (from present observation) perhaps the most reliable, the curve shown in the last column is labeled an "inferred climatic curve," to which the other less empiric curves are related.

\section{Comparison of the Curves}

Considerable agreement exists in each of the three sediment columns between the "generic ratio curve" and

\footnotetext{
${ }^{4}$ Contradictory evidence on the habitat of Globigerinoides conglobatus was found when investigating the occurrence of this taxon in the Quaternary succession of Sites 132 and 125 (see Chapter 46, this volume). There are indications from the wall structure that it is a subsurface dweller (Site 132), and it appears strongly influenced by ecologic factors related to the sapropelitic cycles (Site 125). Yet, its occurrence in the Pliocene samples considered here is in good agreement with the information on its distribution in the present seas.
}

the "inferred climatic curve" supporting an earlier suggestion of the paleoclimatic usefulness of taxa belonging to Globigerina and Globorotalia.

All living species that comprise the "inferred climatic curve" are epipelagic and dwell near the surface of the sea (according to Ruddiman, Tolderlund, and Bé, 1969). They are temperature sensitive (group II of Douglas, 1970; ranking numbers 7,8 and 9 out of 27 species). Their distribution in the North Atlantic shows that we can consider them as indicators of superficial "warm" water. Their actual latitudinal range is from about $45^{\circ} \mathrm{N}(G$. ruber and $G$. sacculifer) to about $40^{\circ} \mathrm{N}$ (G. conglobatus).

Globigerinoides cf. fistulosus is not considered a living species, therefore, we cannot refer to its distribution in plankton tows. The species, as recorded in Pliocene strata from beneath the sea floor of the Mediterranean, has the characteristic proliferations generally limited to the lastformed chamber; therefore, it is identified as $G$. cf. fistulosus in agreement with Bolli (in Bader et al., p. 626, 1970). This taxon is obviously related phylogenetically to Globigerinoides sacculifer and represents the result of a very advanced specialization. Globigerinoides fistulosus (and G. cf. fistulosus as well) is commonly considered a tropical form because of its actual geographic distribution in Pliocene sediments at low latitudes, e.g., in cores from the tropical Pacific (Parker, 1967), Cape Verde Platform (Cita, 1971), and central Caribbean (Bolli, in Bader et al., 1970). Furthermore, it is invariably associated with species which are considered tropical.

Each of these four taxa has been assigned an identical weight in making up the "inferred climatic curve." If no taxa were recorded, we assign the value 0 ; if one $^{5}$ is recorded we have a value 1 and so on. If all are present ${ }^{6}$, we have the maximum value, which is 4 .

A first rough evaluation of the "inferred climatic curve" shows that an interval near the terminal part of the Pliocene, corresponding to a duration of about $1 \mathrm{my}$, possessed a climate that was warmer than during the whole time period preceding. A relatively cold or "cool" interval is found within the Upper Pliocene both at the Tyrrhenian and Mediterranean Ridge (Ionian Basin) drill sites. This period is older than the 2.9 my extinction horizon of Sphaeroidinellopsis as discussed in Chapter 47.2.

Reliable data on climatic changes which occurred in the Lower Pliocene were obtained only from Hole 132 in the Tyrrhenian Basin. The stratigraphic record of Site 125 cannot be used because of very poor core recovery (insufficient for a realistic evaluation) and the record of Site $125 \mathrm{~A}$ can be used only for some intermittent intervals. Thus, the paleoclimatic interpretation for the Lower

\footnotetext{
${ }^{5}$ The initials $\mathrm{C}$ for conglobatus, $\mathrm{F}$ for cf. fistulosus, R. for ruber, $\mathrm{S}$ for sacculifer permits the identification of the taxa recorded at each level of a single occurrence.

${ }^{6}$ Thus, for the paleoclimatic interpretation of the Lower Pliocene, Globigerinoides ruber is here used in a fairly restricted sense. In fact, we plotted it as discrete taxon in our range charts, besides $G$. pyramidalis (Van den Brock), G. elongatus (d'Orbigny) and $G$. helicinus (d'Orbigny) which some authors lump together with $G$. ruber. Only G. ruber (including G. gomitulus [Seguenza], which is also considered discrete by some workers) is considered here.
} 

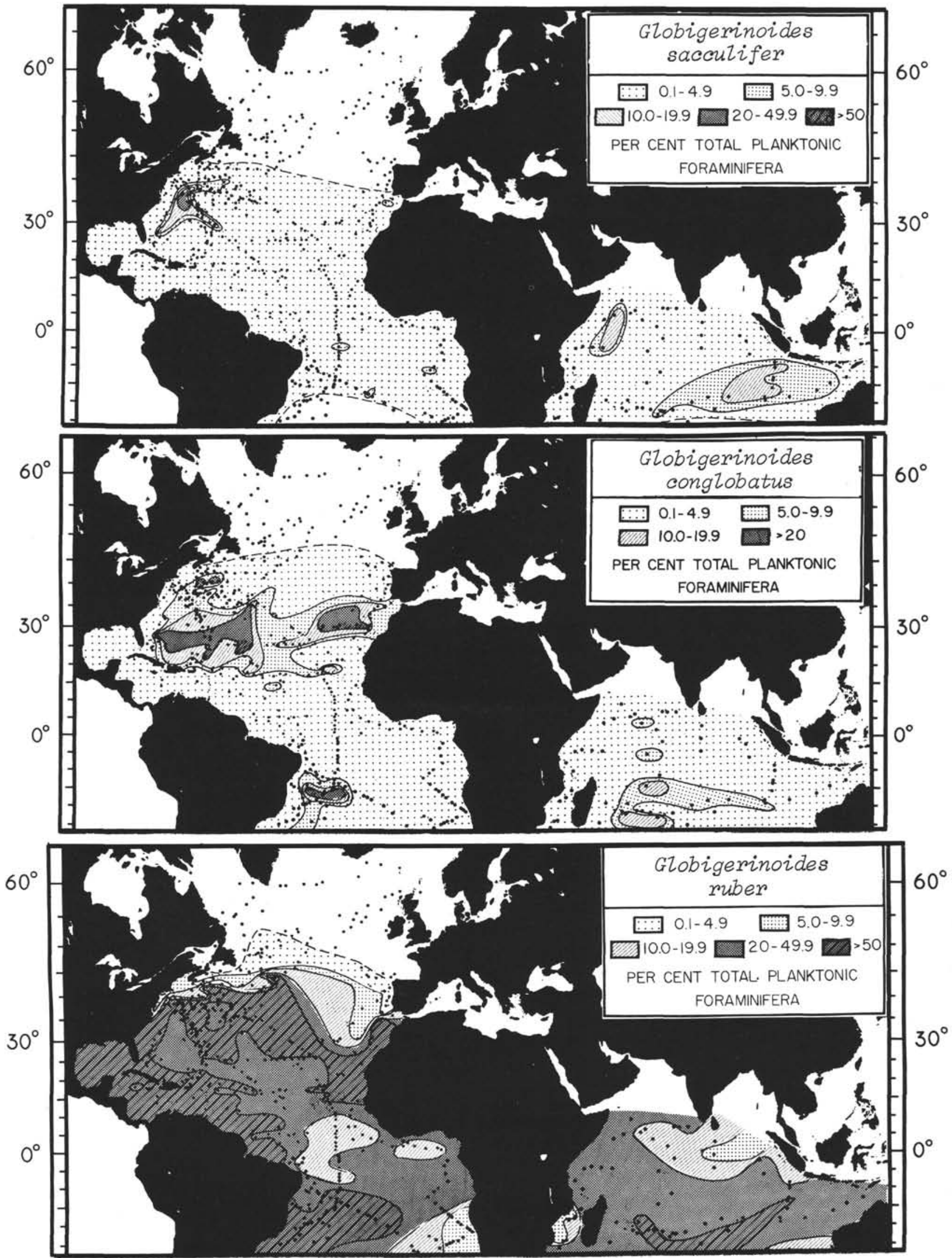

Figure 4. Distribution of relatively abundant Globigerinoides sacculifer, G. conglobatus and G. ruber in the surface waters of the Atlantic and Indian Oceans according to Bé and Tolderlund, 1971. 
Pliocene is more problematic than the interpretation of the Upper Pliocene.

To the objective data connected with the material investigated, we have yet to add inferences deduced from the greater number of extinct species, the paleoecological evaluation of which is questionable. For instance, Globorotalia margaritae, the most conspicuous taxon of the Lower Pliocene and practically the only keeled Globorotalia of that interval, is probably an indicator of warm superficial waters. In fact, it was originally described in a tropical area (Venezuela) and has never been recorded in high latitude areas. It is associated in its type area with other faunistic elements indicating a tropical climate. In addition, all the keeled globorotalids, even those with an acute periphery, which are living in the present seas, are distributed in central water masses or in equatorial seas; perhaps the same distribution also occurred in the past.

Indications from the "inferred climatic curve" which is based on the occurrence of selected warm-water Globigerinoides are not very clear for the interval corresponding to the range of Globorotalia margaritae. This may be partly due, at least so far as the Globorotalia margaritae margaritae Lineage Zone is concerned, to the anomalous oceanographic conditions existing in the Mediterranean after the (catastrophic) Pliocene transgression.

\section{THE INFERRED CLIMATIC CURVES}

A comparison between the "inferred paleoclimatic curves" computed for Holes 125 and $125 \mathrm{~A}$ is easy and immediate. The two wells, in fact, are only about a hundred meters apart and penetrated the same sedimentary succession. Although both of them were continuously cored, the core recovery at each was disappointingly low, usually less than 50 per cent. Only Core 4, Hole 125 , is composed of six complete sections.

In the other cores, which have from one to five sections, the exact in situ position of the recovered sediments within the cored interval cannot be accurately determined. A convention followed during Leg 13 assigns the top of a recovered sediment column to the top of the cored interval, yet this placement cannot actually be verified as correct. The location of sediment cores in the graphic logs of the site chapters is in agreement with the convention. However, there are circumstances where the biostratigraphic and paleoclimatic (inferred) correlation suggests that the conventional assignment is definitely in error and should be disregarded.

\section{Differences in the Regional Climates}

Taking into account some flexibility in the location of recovered sections, it has been possible to integrate the two climatic curves computed for Holes 125 and $125 \mathrm{~A}$ with the one computed for Hole 132. The correlations are shown in Figure 5 and reveal not only sympathetic fluctuations between the "inferred" climates, but, rather interestingly, show that the overall climate at the Tyrrhenian drill site was noticeably cooler than that at the Ionian Basin site some 1000 kilometers $(\simeq 5$ degrees of latitude difference)

\footnotetext{
${ }^{7}$ The sudden transgression is discussed at some length in Chapter 47.1 and is also referred to in Chapter 43.
}

to the southeast. Perhaps we should not be too surprised at this finding since today's mean annual temperatures shows a difference of some 3.0 to $3.6^{\circ} \mathrm{C}$ (Mosetti, personal communication).

The cooccurrence of all four species, as happens at three peaks in Hole 125 A and two peaks in Hole 125, indicates a maximum "warm" condition. Such a happening was not recorded in the more than 100 samples investigated from the Pliocene of Hole 132.

Two out of the four species considered, namely, $G$. ruber and $G$. sacculifer, are usually far more common than the rest. $G$. conglobatus and $G$. cf. fistulosus are rarer and only occur in the warmest intervals. G. conglobatus is recorded in only 5 per cent of the Site 132 samples investigated, while in Hole 125 it occurs in 30 per cent of the samples, and in Hole 125A, in about 20 per cent. Similar observations have been made, concerning $G$. cf. fistulosus.

Indications given by the warm-water Globigerinoides, better represented at Site 125 than at Site 132, are supported by the distribution of some significant Globorotalias in the same samples. For instance, Globorotalia menardii (d'Orbigny) is represented by sparse, right-coiling specimens in Sample 125A-5-1, 108-111 cm, which corresponds to one of the warmest peaks (Plate 5, Figure 3, Chapter 47).

Globorotalia menardii ranges in the Atlantic to about 40 degrees as shown in Figure 6.22 of Bé and Tolderlund, 1971. The taxon, originally described from the beach of Rimini (d'Orbigny, 1826), is not known in recent sediments in the Mediterranean. It has been frequently recorded in Miocene outcrops of the circum-Mediterranean area, but because of climatic exclusion, it apparently never reentered the Mediterranean after the late Miocene desiccation. According to available literature, this is the first record of true Globorotalia menardii of post-Miocene age in the Mediterranean area. Globoquadrina altispira (Cushman \& Jarvis) may also be considered a subtropical form. It is recorded in about 9 per cent of the Site 132 Pliocene assemblages investigated while in Holes 125 and 125 A the same taxon is recorded in 14 per cent and 17 per cent respectively of the assemblages. This result is in good agreement with the other observations previously discussed.

The only stratigraphic record that is sufficiently continuous to allow a climatic interpretation for the Lower Pliocene is, as previously noted, that of Site 132 . It seems that the changes which occurred during the Lower Pliocene were more substantial than those of the earlier part of the Upper Pliocene, though probably less important than the changes recorded in the later part of the Upper Pliocene.

\section{CLIMATIC FLUCTUATIONS AND THE BIOSTRATIGRAPHIC FRAMEWORK}

Six major climatic oscillations have been recognized in the stratigraphic interval between the topmost part of the Lower Pliocene and the Pliocene/Pleistocene boundary. ${ }^{8}$

\footnotetext{
${ }^{8}$ Criteria for recognition of the Pliocene/Pleistocene boundary in the various drill holes is discussed in some detail in Chapter 46 of this volume. The boundary is considered as coincident with the Olduvai event of normal magnetic polarity near the extinction level of Discoaster brouweri and the first appearance of Globorotalia truncatulinoides.
} 


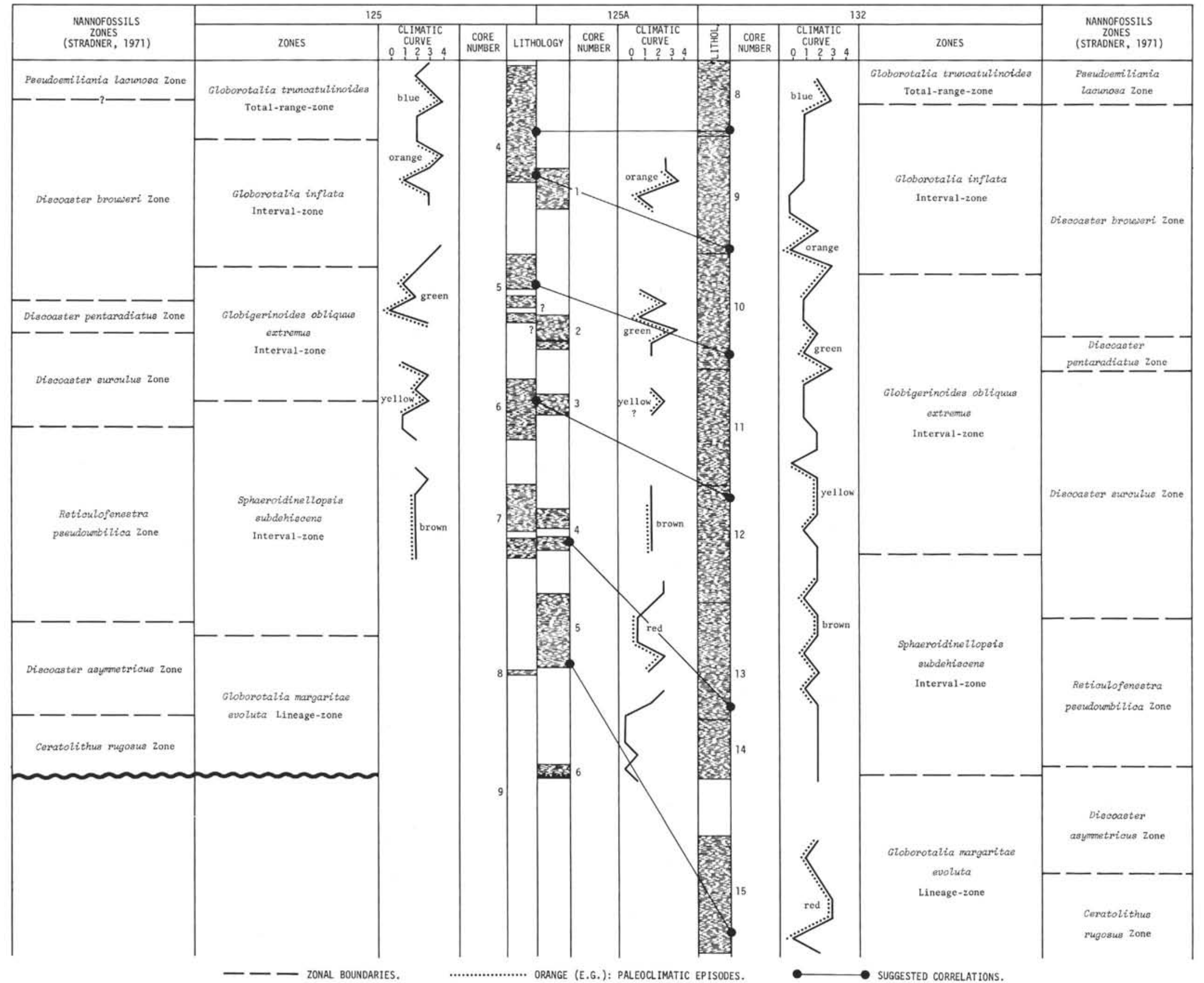

Figure 5. Paleoclimatic and biostratigraphic correlations of the Pliocene successions penetrated in the Ionian Basin (Sites $125-125 \mathrm{~A}$ ) and in the Tyrrhenian Basin (Site 132). 
The individual cycles are cross-correlated between the three drill holes in Figure 5. Each time-equivalent fluctuation has been identified with a color prefix as an aid in visualizing the correlations. The cycles are discussed below in order of increasing age (i.e., from top to bottom).

\section{Blue}

The youngest fluctuation (labeled blue) is a "warm" peak recorded in Holes 125 and 132 just above a horizon which we have distinguished as the Pliocene/Pleistocene boundary. The location in both holes of this distinct inflection point within the Globorotalia truncatulinoides Total-range Zone, corroborates the conclusion of Emiliani et al. (1961) that this important boundary was not associated with cooling of the regional climates. Our result also agrees well with what has been found by Bandy and Wilcoxon (1970) in Italy and California.

\section{Orange}

The next lower fluctuation (orange) consists of two "warm" peaks separated by a "cold" interval of short duration. It is detectable in all three holes.

The peaks can be considered quite "warm" since they are registered at the highest value (4) of the "inferred climatic curves." The orange fluctuation is located near the boundary between the Globorotalia inflata Interval Zone and the Globigerinoides obliquus extremus Interval Zone, at a chronological level corresponding to $\approx 2.1$ to $2.3 \mathrm{my}$ as estimated from the paleomagnetic record using uniform rates of sedimentation. The minimum between the two warm peaks is probably correlatable with a level of "cold" faunas recorded by Lona (1962) in the late Pliocene (Astian) of Northern Italy and by Bandy and Wilcoxon (1970) in the late Pliocene of California.

\section{Green}

Another distinct fluctuation (green), with two peaks separated by a minimum, occurs in all three holes near the middle of the Globigerinoides obliquus extremus Interval Zone. The "inferred climatic curves" again reach their highest value at the lower of the two peaks. The age of the green fluctuation is estimated at approximately 2.5 to 2.6 my.

\section{Yellow}

A climatic fluctuation (yellow) is observed in Holes 125 and 132. It lies immediately above the Sphaeroidinellopsis extinction datum, which corresponds to the top of the Mammoth paleomagnetic event (Hays et al., 1969) or $\simeq 2.9$ my. (Datum V of Saito, in Hays et al., 1969). This fluctuation appears in both sites in the lower part of the Globigerinoides obliquus extremus Interval Zone. The trend of the "inferred climatic curve" at this level is very similar at both sites.

\section{Brown}

An interval, characterized by rather uniform and low values of the climatic curve (brown), is present in all the sections considered in the earlier part of the Upper Pliocene (Sphaeroidinellopsis subdehiscens Interval Zone). It lies between the extinction horizons of Globorotalia margaritae
(=Datum VI of Saito in Hays et al., $1969=$ GilbertMatuyama boundary dated at $3.32 \mathrm{my}$ ) and the extinction horizon of Sphaeroidinellopsis spp. (=Datum VII of Saito, op.cit.). This broad "cool" period, centered at 3 my ago, is most likely equivalent to the one outside the Mediterranean realm recognized by Lamp (1969) in deposits from the Gulf of Mexico and interpreted by him as corresponding to the base of the Nebraskan. Radiometrically, it can be tied to the oldest dated galcial deposits in the Sierra Nevada and Iceland (Savage and Curtiss, 1970). Bilstratigraphically, it is equivalent to the onset of ice-rafted materials in the Labrador Sea as is evidenced by strata of Discoaster asymmetricus-Discoaster surculus age recovered during Leg 12 of the Deep Sea Drilling Project, discussed by C. Perch-Nielsen in Volume 12 of the Initial Reports (in preparation).

We suggest that the brown fluctuation of periodic "cool" climates is time correlatable to the Acquatraversa erosional phase of Blanc (1955), recognized in outcrops near Rome. ${ }^{9}$

With reference to the stratotype sections of the Pliocene stages, as defined in northern Italy, it must be pointed out that most of the Piacenzian Stage, as defined by Mayer (1857) and stratotypified by Barbieri (1967), falls above the "cool" interval under discussion. Yet, this period has been considered by some authors working in marine sections, including Lamb (1969) and Blanc (1955), as the beginning of the Quaternary. To accept the Pliocene/ Pleistocene boundary at about 3 my would imply that the classical faunal assemblages of the section of Castellarquato should be excluded from the Pliocene. Since this section has been used worldwide in biostratigraphic correlations, we prefer to keep it in the Pliocene.

\section{Red}

A fluctuation (red), characterized, from top to bottom, first by a cooling on the climatic curve, then by warming and finally by another cooling, is observed in the sediment columns of Holes 132 and 125A near the top of the Lower Pliocene (Globorotalia margaritae evoluta Lineage Zone) and immediately prior to the extinction horizon of Globorotalia margaritae.

\section{Magnitude of the Fluctuations}

It is seen from the previous discussion that two accentuated fluctuations are recorded in the later parts of

\footnotetext{
${ }^{9}$ The Acquateraversa erosional phase has until now been considered the base of the sediments of the oldest Pleistocene sequences. However, according to Ambrosetti, Azzaroli, Bonadonna, and Follieri (1970-1971) no direct age measurements can be made. Nevertheless, a working hypothesis may be proposed. At Roccastrada (Southern Tuscany), a volcanite $2.3 \mathrm{my}$ old rests on a paleosurface implanted on gravelly-sandy sediments, referred in the literature to the Upper Pliocene (Geological Map of Italy, Sheet 120 "Siena," 1968). In the area of Cerveteri (Rome), a lava of the "Cerite Complex," $3.7 \pm 0.15$ my old, underlies a thick gravelly complex which may probably be correlated with an intense erosional phase. There seems some evidence for at least one erosional phase between these two dates. The most plausible hypothesis is that this phase corresponds to one or more cold episodes recorded in several parts of the world between 2.8 and 3.1 my.
} 
the Upper Pliocene (Globigerinoides obliquus extremus Interval Zone and the Globorotalia inflata Interval Zone. Amplitude of the fluctuations, as judged from the faunal populations, are as large as those recorded in younger strata at Sites 125 and 132 which belong to the "pre-Glacial" Pleistocene, but are not as great as those lying within the "Glacial" Pleistocene (see discussion in Chapter 46 for a distinction between the "Glacial" and "pre-Glacial" Pleistocene).

Unlike the history of the "Glacial" Pleistocene, as recorded layer-by-layer in the deep-sea sediments of the Mediterranean Sea, the record of the Upper Pliocene does not reveal successive "cold" periods. The changes here are predominantly from "warm-temperate" to "temperate." It may be surprising that the interglacial periods of the Quaternary are characterized by foraminiferal assemblages even warmer than those of the warmest Upper Pliocene peaks. Besides the four Globigerinoides species here considered, other tropical indicators occur, such as Candeina nitida d'Orbigny (recorded in sample 130-1-1) and Pulleniatina obliquiloculata (Parker and Jones) (recorded in sample 120-4, CC and in Sample 134E, Side Wall Core 1). These taxa are known to have existed in other oceans through the Upper Pliocene, but have not been found in any of the samples investigated from this time period in the Mediterranean Sea, thus suggesting that during the interglacials of the Quaternary the climate was even warmer than in the warmest periods of the Pliocene.

\section{Periods of Stagnation}

It has to be pointed out that the lower sapropelitic layer cored on the Mediterranean Ridge (Site 125A, Core 2-2, lower part) is located just below the lower peak of fluctuation "green" in the Globigeriniodes obliquus extremus Interval Zone. The euxinic episode coincides with a warming trend on the "inferred climatic curve" analogous to many of the brief periods of stagnation found in the later part of the Quaternary (Ryan, 1971).

Our findings are in good agreement with the model of Olausson (1961) wherein the deposits of sapropelitic mud, characteristic of stagnant conditions above the sea floor, are formed during periods of rising sea level accompanying the world-wide warming of climates and melting of the ice sheets. The findings from Holes 125 and 132 would suggest that significant glacio-eustatically controlled changes in sea level occurred in the Mediterranean a long time (perhaps some $1.5 \mathrm{my}$ ) before the onset of actual glaciation in the circum-Mediterranean area.

\section{SUMMARY OF MAJOR CONCLUSIONS}

The investigations carried out on the planktonic foraminiferal assemblages reveal significant fluctuations in the faunal composition which appear to be the result of an ecologic influence rather than evolutionary change.

A number of species living in Pliocene time are extinct and their depth habitat is unknown. Therefore, to use them as climatic indicators would have led to unfounded reconstructions. To avoid uncertainties concerning the behavior of mesopelagic or abyssopelagic taxa, considered to be not particularly sensitive to temperature, attention was concentrated on taxa living in pre-Quaternary times at the surface of the sea (epipelagic). The taxa considered have a definite climatic significance supported by their distribution in the present world ocean. These are Globigerinoides conglobatus, G. cf. fistulosus, G. ruber, and $G$. sacculifer. Curves, plotting their occurrences in the various sections from the Ionian and Tyrrhenian Basins, have been used as "inferred climatic curves."

Six definite changes or fluctuations can be recognized and correlated between Sites 132 and 125, which are some $1000 \mathrm{~km}$ apart. Their stratigraphic position is controlled with reference to the foraminiferal and nannoplankton biozonation.

Among the most significant climatic changes or fluctuations are a number of sharp ("warm") peaks, separated by a minima ("cool" intervals), in the later parts of the Upper Pliocene between about 2.1 and $2.6 \mathrm{my}$. The lowermost sapropel layer recorded at Site 125A (Section 2 of Core 2) occurs along a warming trend in the "inferred climatic curve" that lies within the Globigerinoides obliquus extremus Interval Zone.

Sapropelitic cycles are known to occur in deep sea deposits of Quaternary age in the eastern Mediterranean from piston cores collected during the Swedish Deep Sea Expedition (1946-47). The model proposed by Olausson (1961) and Ryan (1971) for their origin involves glacioeustatic control of sea level leading to a connection between the Black Sea and the eastern Mediterranean during periods of high sea level.

It was discovered from the deep-sea drilling that Sapropelitic cycles have occurred not only in glacial times, but also in the "pre-Glacial" Pleistocene and in the later parts of the Upper Pliocene. The position of the sapropelitic layers with reference to the "inferred climatic curve" would suggest that important glacio-eustatic changes in sea level also occurred a long time before the onset of glaciation in the circum-Mediterranean region.

Another distinct climatic change, which indicates a period of relatively cold or cool climate, has been observed in all the sections investigated. Its position, with respect to the biohorizons correlated to the magnetic stratigraphy and absolute chronology, indicates an age approaching 3 my. This age corresponds well with the base of the Nebraskan (as recorded in the Gulf of Mexico), to the onset of ice-rafted detritus in the Northern Atlantic (as determined from Leg 12 of the DSDP), and with the middle Villafranchian continental fauna. This cold interval is considered by many authors as the beginning of the Quaternary; however, the adoption of such a boundary is inconsistent with the boundary as defined at the INQUA Congress (1955) and with the type sections of the Piacenzian Stage in Northern Italy.

\section{ACKNOWLEDGMENTS}

We are grateful to Professor A. Valduga for the interest demonstrated in this investigation as well as for the opportunity afforded one of (N.C.) to spend some months in Milan at the Laboratory of Micropaleontology.

The manuscript was critically read by Professor C. Rossi Ronchetti, Director of the Institute of Paleontology of the University of Milan, by Professor A. Valduga, Director of the Institute of Geology and Paleontology of the University 
of Bari, and by W. B. F. Ryan of the Lamont-Doherty Geological Observatory of Columbia University.

The authors wish to acknowledge numerous valuable discussions with professors A. Longinelli (University of Pisa), A. Azzaroli (University of Florence), M. Merlin (University of Venice), and F. Mosetti (University of Trieste).

Technical assistance was provided by M. Zocchi, E. Gagliardi, R. Lasalandra and C. Chiapperi.

The research was supported in part by grants from Consiglio Nazionale delle Ricerche, Comitato 05.

\section{REFERENCES}

Ambrosetti, P., Azzaroli, A., Bonadonna, F. P. and Follieri, M., 1971. Scheme of Pleistocene Chronology for the Tyrrhenian side of Central Italy. Bull. Soc. Geol. Ital. XC (4).

Azzaroli, A., 1970. Villafranchian correlations based on large Mammals. C.M.N.S. Proc. IV, Giorn Geol. s. 2, 35,1 .

1971. Report of the working group on continental Pleistocene, Commissione Stratigrafica del Comitato Geologico d'Italia, Roma (unpublished).

Bandy, O. L. and Wilcoxon, J. A., 1970. The PlioPleistocene boundary, Italy and California. Bull. Geol. Soc. Am. 81, 2939.

Barbieri, F., 1967. The foraminifera in the Pliocene section Vernasca-Castell' Arquato including the Piacenzian stratotype (Piacenza province). Mem. Soc. It. SC. Nat. Milano. 15 (3), 115.

Bé, A. W. H., 1959. Ecology of recent planktonic foraminifera: part 1. Areal distribution in the western North Atlantic. Micropaleontology, 5, 77.

1960. Ecology of recent planktonic foraminifera: part 2. Bathymetric and seasonal distribution in the Sargasso Sea off Bermuda. Micropaleontology, 6, 373 .

Bé, A. W. H. and Hamlin, W. H., 1967. Ecology of recent planktonic foraminifera: part 3. Distribution in the North Atlantic during summer of 1962. Micropaleontology, 13, 87 .

Bé, A. W. H. and Tolderlund, D. S., 1971. 6. Distribution and ecology of living planktonic Foraminifera in surface waters of the Atlantic and Indian Oceans. Micropaleontology of Oceans. Funnel, B. M., (Editor), Cambridge Univ. Press, London, 105.

Bertolino, V. et al., 1968. Proposal for a biostratigraphy of the Neogene in Italy based on planktonic foraminifera. Proc. IV Sess. C.M.N.S., Giorn. Geol., s. 2, 35, 23.

Bolli, H. M., 1970. (in Bader et al.). The foraminifera of sites 23-31, Leg IV, Chapter 25. Initial Reports of the Deep Sea Drilling Project, Volume 4. Washington (U.S. Government Printing Office). 578.

Boltovskoy, E., 1969. Foraminifera as hydrological indicators, Int. Conf. on Plankt. microfossils, 2, 1.
Cati, F., et al., 1968. Biostratigrafia del Neogene mediterraneao basata sui foraminiferi planctonici. Boll. Soc. Geol. It. 87, 491.

Cifelli, R., 1965. Planktonic foraminifera from the Western North Atlantic. Smiths. Contr. to Paleobiol. 4, 1. (in press). On the temperature relationships of planktonic foraminifera.

Cita, M. B., 1971. Biostratigraphy, chronostratigraphy and paleo-environment of the Pliocene of Cape Verde (North Atlantic). Rev. de Microp.

Cita, M. B. and Ciaranfi, N., 1971. Evidence of climatic changes in the deep-sea Pliocene of the Mediterranean. Compt. Rend. $d u V^{\circ}$ Cong. Int. du Neog. Mediterr. Lyon. In press.

Douglas, R. G., 1970. Time-dependent variation in surface oceanic current. Preprint.

Emiliani, C., Mayeda T. and Selli, R., 1961. Paleotemperature analysis of the Plio-Pleistocene sections at Le Castella, Calabria, Southern Italy. Bull. Geol. Soc. Am. 72, 679 .

Hays, J. D., Saito, T., Opdyke, N. D. and Burckle, L. M., 1969. Pliocene-Pleistocene sediments of the Equatorial Pacific: their paleomagnetic, biostratigraphic and climatic record. Bull. Geol. Soc. Am. 80, 1481.

Lamb, J. L., 1969. Planktonic foraminiferal datums and late Neogene Epoch boundaries in the Mediterranean, Caribbean, and Gulf of Mexico. Trans. Gulf. Coast Ass. Geol. Soc. 19, 559.

Lona, F., 1962. Prime analisi polliniche sui 'depositi terziari-quaternari di Castell 'Arquato: reperti di vegitazione da clima freddo sotto le formazioni da clima freddo sotto le formazioni calcaree ad Amphistegine. Boll. Soc. Geol. It. 81 (1), 89.

Mayer, C., 1857-58. Versuch einer syncronischen Tabelle der Tertiar Gebilde Europa. Verh. Schwei. Naturf. Ges., Trogen.

Olausson, E., 1961. Studies of deep-sea cores. Sediment cores from the Mediterranean Sea and Red Sea. Rept. Swed. Deep-Sea Exped, 1947-48. 8, 337.

Olson, R. K. and Goll, R., 1970. Upper Tertiary biostratigraphy: Sites 32, through 37, Initial Reports of the Deep Sea Drilling Project, Volume 5. Washington (U.S. Government, Printing Office) 557.

Parker, F. L., 1967. Late Tertiary biostratigraphy (planktonic foraminifera) of tropical Indo-Pacific deep-sea cores. Bull. Am. Paleont. 52 (235), 115.

Ruddiman, W. F., Tolderlund, D. S. and Bé, A. W. H., 1969. Foraminiferal evidence of a modern warming of the North Atlantic Ocean. Deep-Sea Res. 17, 141.

Ryan, W. B. F., 1971. Stratigraphy of Late Quaternary Sediments in the eastern Mediterranean. Proc. VII Internat'l. Cong. Sedim. Heidelberg, (in press) Sedimentation in the Mediterranean, Stanley, D. J., (Editor), Smithsonian Press.

Savage, D. E. and Curtis, G. H., 1970. The Villafranchian Stage. Age and its radiometric dating. Bull. Geol. Soc. Am., Spec. Paper no. 124, 207. 